\title{
Home-made cider brandy (Calvados): analysis of distillation fractions by gas chromatography-mass spectrometry method
}

\author{
Indrè Vaičikauskyt $\dot{e}^{1}$, \\ Vilius Poškus ${ }^{1}$, \\ Vytautas Nekrošius ${ }^{2}$, \\ Vida Vičkačkaitė ${ }^{1}$ \\ Aivaras Kareiva $^{1^{*}}$ \\ ${ }^{1}$ Institute of Chemistry, \\ Faculty of Chemistry and Geosciences, \\ Vilnius University, \\ 24 Naugarduko Street, \\ 03225 Vilnius, Lithuania \\ ${ }^{2}$ Department of Private Law, \\ Faculty of Law, \\ Vilnius University, \\ 9 Sauletekio Avenue, \\ 10222 Vilnius, Lithuania
}

\begin{abstract}
In this study, the distillation fractions of cider brandy produced illegally in Lithuania using gas chromatographic-mass spectrometry method were investigated. The conditions of gas chromatography-mass spectrometry were firstly optimized. A qualitative analysis of three distillation fractions was performed and estimated. The first fraction (initial) of distillation products was collected for $0.5 \mathrm{~h}$, the second one (intermediate) was collected for the next $1.5 \mathrm{~h}$ and the third (main) fraction for the next $5 \mathrm{~h}$. A method of the quantitative analysis of different volatile analytes such as acetaldehyde, methanol, ethanol, 1-propanol, isobutanol, 1-butanol, isoamyl alcohol and benzyl alcohol in the distillation products was also developed. The concentration of ethanol decreased significantly in the main fraction in comparison with those of the initial and intermediate fractions. The concentration of 1-propanol, isobutanol, 1-butanol and isoamyl alcohol in the last fraction decreased drastically as well.
\end{abstract}

Keywords: cider brandy, home-made, distillation, volatile compounds, analysis, gas chromatography, mass spectrometry

\section{INTRODUCTION}

Calvados is an apple brandy native to the Normandy region of France in the 16th century. It is a common drink in the regions of Western Europe, where vineyards are not productive but varieties of apple grow [1, 2]. Calvados can be made not only from apples, but for a more varied taste pears could be mixed together with apples [3]. As many products in the French region have unique traditions, as well as the peculiarities of Calvados production, they are controlled by the National Origin and Quality Institute AOC. In order to extract its tradi-

\footnotetext{
* Corresponding author. Email: aivaras.kareiva@chgf.vu.lt
}

tional taste, preserve the quality and old traditions, the certain rules have been laid down for the production of Calvados, such as fermented apple varieties, type of fermentation and distillation. Also, according to the AOC, three main production of Calvados regions, namely the Pays d'Auge, Calvados and Domfronte, are distinguished. Apple brandy produced in other regions is called cider brandy 4-9]. Calvados is obtained by distilling apple cider. Cider for calvados is made from more than 200 local apple varieties. Fruits are collected and pressed into the juice, which is then fermented. After cider distillation, Calvados is matured in oak barrels. Calvados production consists of three stages: cider production, distillation and maturation [10]. 
In many European countries, the production of strong alcohol is legal activities for small business companies or/and individual farmers. However, this is not the case in Lithuania. According to the Criminal Codex of the Republic of Lithuania, the manufacture, storage, transport, sale or other disposal of vodka or other home-made spirits, as well as the manufacture, storage, transport, sale or other disposal of apparatus for their production, are punishable by up to 3-year imprisonment and/ or a penalty only [11]. This is documented in Article 310 (Manufacture, Storage, Transportation and Sale of Vodka, Other Home-made Spirits, Denatured Ethyl Alcohol, Denatured Ethyl Alcohol, Technical Ethyl Alcohol and Their Mortars, Apparatus for Their Production). Under this Article, the production, storage, transport, sale or other disposal of domestic beer shall not be criminally punishable.

The law of the EU countries defines the procedure for the certification of traditional home-made distilled beverages, the requirements for their production, the amount of taxes, quality standards, permitted production quantities, etc. Meanwhile, in Lithuania the civil servants started to discuss this issue only in 2004. Today, all the necessary legislative changes have been prepared. All that is needed is the decision of the members of the Seimas of the Republic of Lithuania. Those who are most opposed to the emergence of such a law argue that it will not be possible to ensure the quality of alcohol, and the appropriate chemical composition during home production.

The main compounds found in distilled alcoholic beverages are volatile [12-15]. The quality and type of beverages depend on the quantity of these compounds [16-19]. Hundreds of different flavours are found in brandy such as aldehydes, esters and higher alcohols. The most important ingredients of alcoholic beverage are obtained during the production process, i.e. fermentation and distillation [20]. For the identification of compounds, scientists mostly use gas chromatographic-mass spectrometry (GC-MS) that allows the components of the mixture to be separated and identified using a mass spectrometer library [13, 16].

Apples are a fairly popular raw material for alcoholic beverages. A wine, cider, whiskey and brandy could be produced from apples. Cider and cider brandy are the most commonly produced and popular in Lithuania. However, the production of cider brandy is prohibited. Cider brandy is rich in the variety of flavours and aromas formed during fermentation, distillation and maturation. The main aim of this work is to apply a direct method of introducing aqueous solutions and to investigate the distillation fractions of cider brandy produced illegally in Lithuania using gas chromatographic-mass spectrometry method.

\section{EXPERIMENTAL}

\section{Reagents and characterization}

To prepare stock standard solutions the following reagents were used: methanol (99.9\%, Merck), acetaldehyde (99.5\%, Sigma-Aldrich), 1-propanol (99.7\%,Sigma-Aldrich), isobutanol(99.5\%,Merck), 1-butanol (HPLC, Eurochemicals), isoamyl alcohol (98.0\%, Merck), benzyl alcohol (99.0\%, Alfa-Aesar), ethanol (96.3\%, Vilnius Degtinè) and acetone (99.8\%, Sigma Aldrich). In the analysis process, chromatographic vials ( $2 \mathrm{ml}$ capacity), an analytical balance (Kern.), a variable volume automatic pipette $(1 \mathrm{ml})$, volumetric flasks $(500,50$, 20 and $10 \mathrm{ml})$, a micro syringe $(1 \mathrm{ml})$ and Pasteur pipettes were used. For gas chromatography and mass spectrometry analysis Perkin-Elmer Clarus 580 S chromatography equipment and a PerkinElmer Clarus 560S quadrupole mass spectrometer were used. Capillary ZB-WAXplus column (30 m long, $0.32 \mathrm{~mm}$ internal diameter and stationary phase layer thickness $1 \mu \mathrm{m}$ ) was used for chromatographic analysis. The PEG polymer was used as a stationary phase of this column. The column was chosen for its stability in an aqueous medium, it can be repeatedly analyzed and the selectivity in the analysis of aqueous alcohol samples can be ensured.

\section{Gas chromatographic-mass spectrometric analysis conditions}

The gas chromatographic analysis was performed in the temperature programming mode. The change of temperature over time is shown in Fig. 11. The temperature of an injector was $200^{\circ} \mathrm{C}$. The total analysis time of one sample was $19.6 \mathrm{~min}$. The carrier gas flow was $1.4 \mathrm{ml} / \mathrm{min}$. A sample inlet with sharing flow was used. The flow split was chosen to be 1:30. The volume of the injected sample was $0.5 \mu$. 


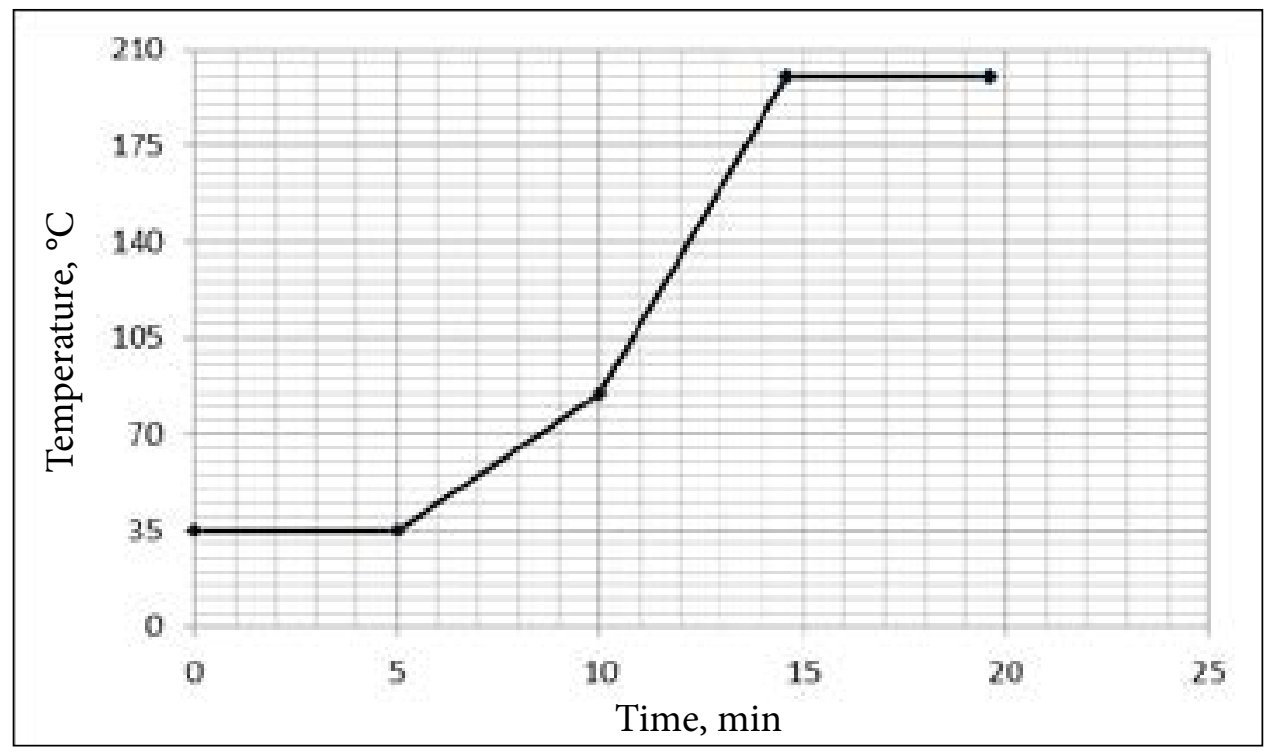

Fig. 1. Changes of the temperature of a column thermostat over time

Electron beam ionization (EI) was used during the mass spectrometry study. The temperature of the gas chromatograph and mass spectrometer interface was $250^{\circ} \mathrm{C}$. For the qualitative and quantitative analysis of alcohols the spectrometer was set to the scan mode scanning ions with $\mathrm{m} / \mathrm{z}$ from 30.00 to 400.00 . For the impurity alcohol analysis the scan was performed from 1 to $19.6 \mathrm{~min}$. The scanning was turned off from 5.1 to $6.2 \mathrm{~min}$ in order do not collect the solvent signal, which reloads the detector. For the determination of ethanol concentrations, the scan was performed from 3 to $19.6 \mathrm{~min}$, thus not collecting the acetone signal used as a solvent for this study.

\section{Preparation of samples for analysis}

For the quantitative analysis of the compounds, standard alcohol solutions in the concentration range of $0.0025-2.0 \mathrm{mg} / \mathrm{ml}$ were prepared. The solvents ethanol and acetone were chosen for the preparation of the standard solutions. The solvents were selected according to the known rule - like dissolves like. Because the analyzed compounds are polar, the polar solvents have been selected. The choice of ethanol was determined by its large amounts in the studied objects. To determine the concentration of ethanol, a standard solution was prepared in acetone. This solvent was also used to dilute samples. For the quantitative analysis of ethanol, 500-fold dilution was performed due to its high concentration in the sam- ple that overloaded the column and detector. The same acetone was selected as a solvent. By applying such dilution, it was possible to measure the ethanol concentration in the range of the calibration curve.

\section{RESULTS AND DISCUSSION}

Figure 2 shows that under the optimized conditions a complete separation of all analytes of the standard solution was achieved. For the qualitative and quantitative analysis of cider brandy, three fractions of cider brandy distillation are investigated in this study. The first fraction (initial, A) of distillation products was collected for $0.5 \mathrm{~h}$, the second one (intermediate, B) was collected for the next $1.5 \mathrm{~h}$ and later the third fraction (main, C) for the next $5 \mathrm{~h}$. For the quantitative analysis no separate sample preparation is required. The three cider brandy fractions poured separately into chromatographic vials were tested in the GC-MS system. The direct sample injection into the system was used. The obtained chromatograms of the samples are presented in Fig. 3. The peaks of the analytes were identified using the MS library. The detected volatile compounds of different distillation fractions of cider brandy are presented in Table 1. The compounds detected in the fractions differ because the fractions are collected by different time of distillation. The chromatograms of the first and second fractions are similar only 


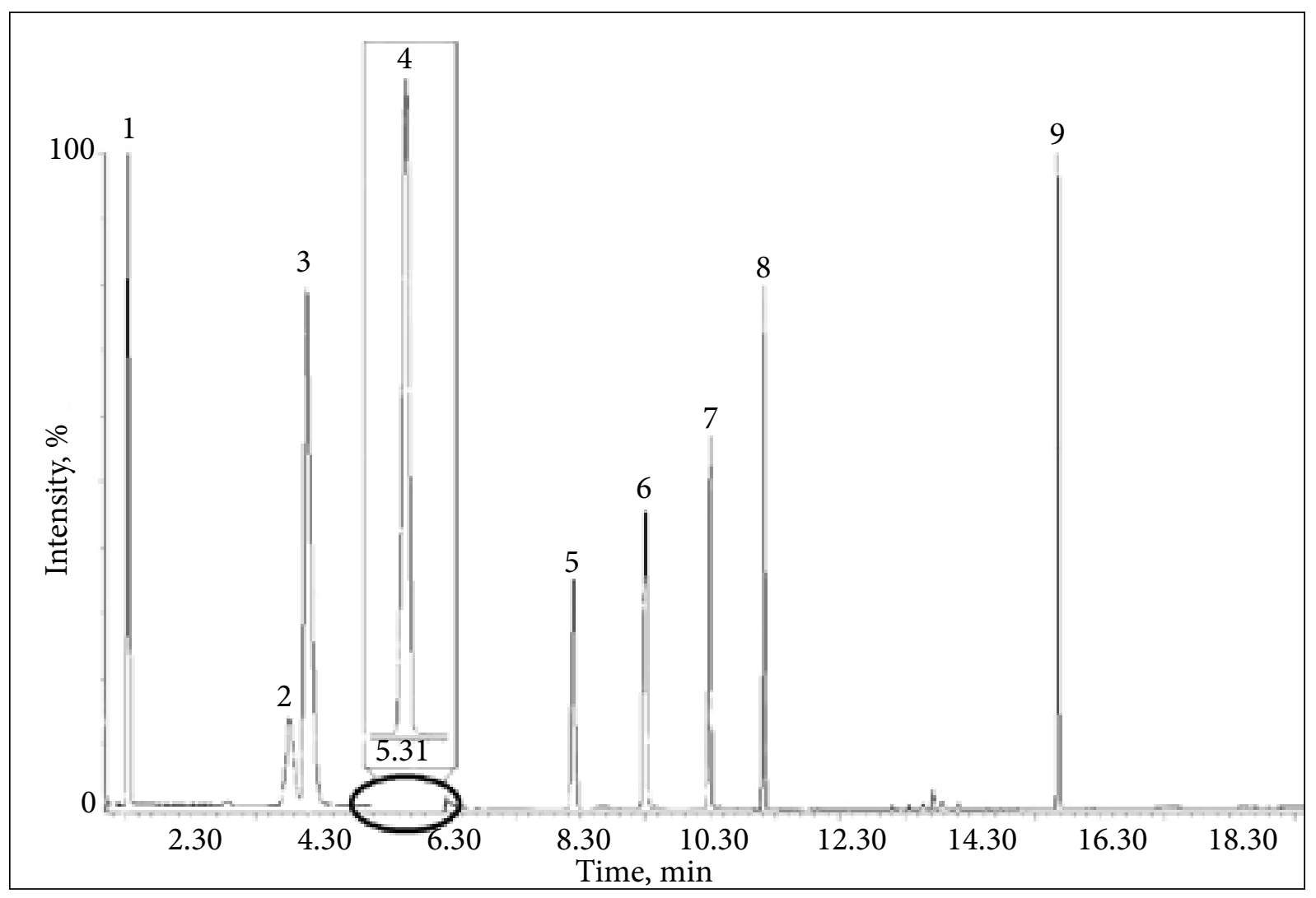

Fig. 2. The chromatogram of the standard solution: 1, acetaldehyde; 2, ethyl acetate; 3, methanol; 4, ethanol; 5, 1-propanol; 6, isobutanol; 7, 1-butanol; 8, isoamyl alcohol; 9, benzyl alcohol

with different peak intensities. On the other hand, the initial fraction in comparison with the intermediate fraction contains extra volatile compounds, such as isobutyl acetate, ethyl butyrate, ethyl hexanoate and ethyl octanoate. Evidently, the main third fraction is the purest product of distillation. The results show that many compounds in the third distillation fraction are no longer detectable. In this fraction, seven volatile compounds were determined and the intensities of the peaks in the chromatogram are significantly reduced.

The change of the peak areas of the detected compounds in the distillation fractions was evaluated. Since the peak intensities were highest in the first fraction, it was taken as a reference for the evaluation of a decrease in the peak area observed in other fractions. Table 2 shows the results of a decrease in the peak area by several times. A significant decrease in the peak area of isoamyl acetate in the second fraction is clearly visible compared to that of the first fraction. Interestingly, the peak areas of acetaldehyde and 1-propanol in the fraction $\mathrm{C}$ are about 30 and 20 times, respectively, lower than in the fraction A. Moreover, the peak area of ethyl acetate decreased almost 475 times.

The quantitative evaluation of the representative volatile compounds was also performed. Because of the lack of standard substances, the concentrations of selected distillation products, namely acetaldehyde, methanol, ethanol, 1-propanol, isobutanol, 1-butanol, isoamyl alcohol and benzyl alcohol, were measured. A stock standard solution with a concentration of $2.0 \mathrm{mg} / \mathrm{ml}$ of these compounds was prepared. For the preliminary determination of analytes the GC-MS system was calibrated for all compounds except for ethanol (its concentration is significantly higher) in the range of $5 \mu \mathrm{g} / \mathrm{ml}-2 \mathrm{mg} / \mathrm{ml}$. The signal for acetaldehyde and benzyl alcohol at $5 \mu \mathrm{g} / \mathrm{ml}$ was non-intense, therefore $10 \mu \mathrm{g} / \mathrm{ml}$ was chosen as the lowest point of the calibration curves for these compounds. For ethanol quantification, the instrument was calibrated at $0.1 \mathrm{mg} / \mathrm{ml}-2 \mathrm{mg} / \mathrm{ml}$ [21]. The calibration curves are shown in Fig. 4 . As seen, the calibration curves for all compounds correspond to the straight line equation with 


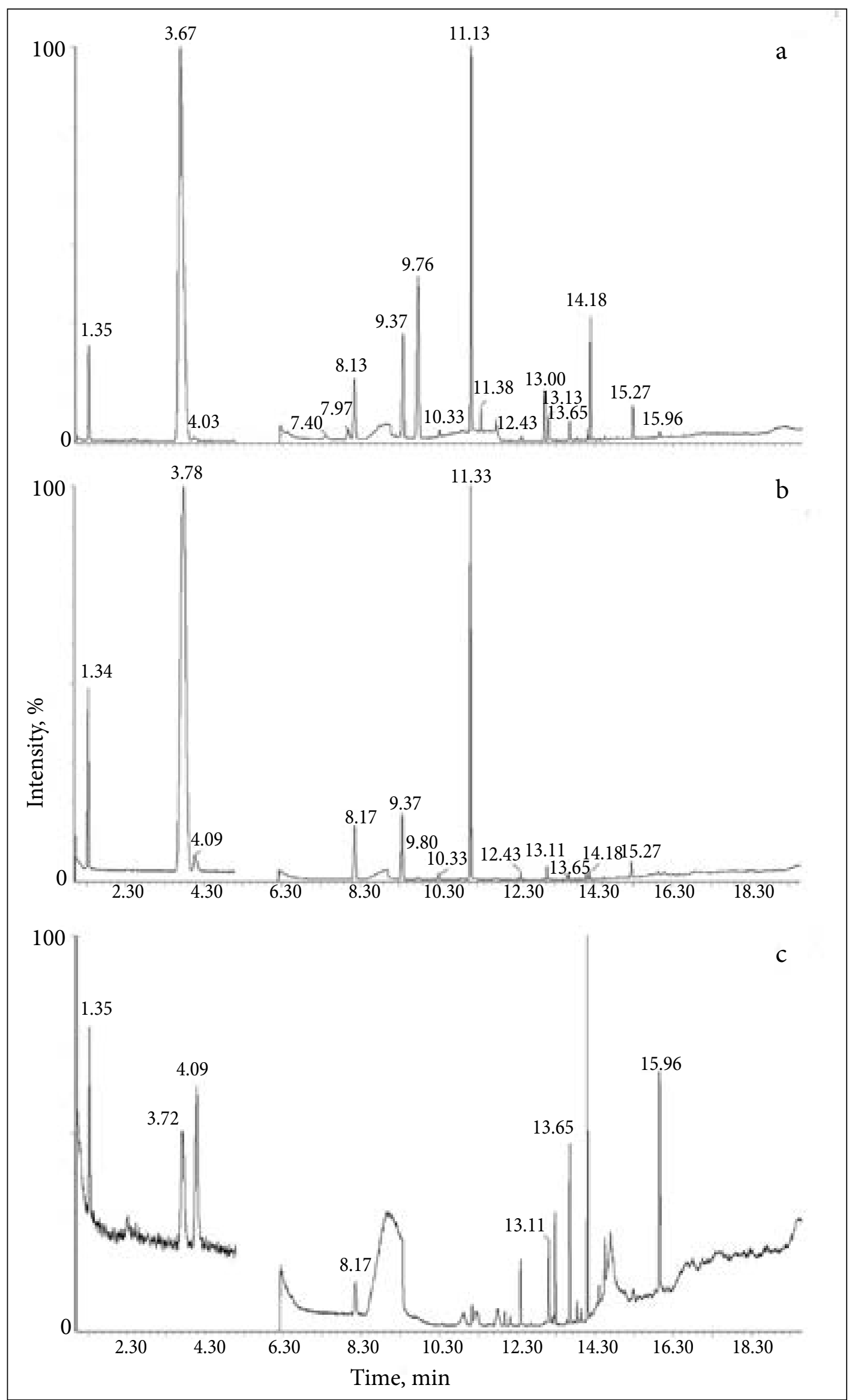

Fig. 3. The chromatograms of three distillation fractions $A, B$ and $C$ of cider brandy 
Table 1. Volatile compounds determined from the distillation fractions of cider brandy

\begin{tabular}{|c|c|c|c|}
\hline \multirow{2}{*}{ Compound } & \multicolumn{3}{|c|}{$R t$, min } \\
\hline & Fraction A & Fraction B & Fraction C \\
\hline Acetaldehyde & 1.35 & 1.34 & 1.35 \\
\hline Ethyl acetate & 3.67 & 3.78 & 3.72 \\
\hline Methanol & 4.03 & 4.09 & 4.09 \\
\hline Isobutyl acetate & 7.40 & - & - \\
\hline Ethyl butyrate & 7.97 & - & - \\
\hline 1-Propanol & 8.13 & 8.17 & 8.17 \\
\hline Isobutanol & 9.37 & 9.37 & - \\
\hline Isoamyl acetate & 9.76 & 9.76 & - \\
\hline 1-Butanol & 10.33 & 10.33 & - \\
\hline Isoamyl alcohol & 11.13 & 11.13 & - \\
\hline Ethyl hexanoate & 11.38 & - & - \\
\hline Hexanol & 12.43 & 12.43 & - \\
\hline Ethyl octanoate & 13.00 & - & - \\
\hline Acetic acid & 13.13 & 13.11 & 13.11 \\
\hline 2,3-Butanediol & 13.65 & 13.65 & 13.65 \\
\hline Decanoic acid & 14.18 & 14.18 & - \\
\hline Lauric acid & 15.27 & 15.27 & - \\
\hline Benzyl alcohol & 15.96 & 15.96 & 15.96 \\
\hline
\end{tabular}

Table 2. The results of the decrease in the peak area in distillation fractions $B$ and $C$

\begin{tabular}{c|c|c}
\hline \multirow{2}{*}{ Compound } & \multicolumn{2}{c}{ Decrease in peak area (times) } \\
\cline { 2 - 3 } & Fraction B & Fraction C \\
\hline Acetaldehyde & 4.0 & 29.6 \\
\hline Ethyl acetate & 5.4 & 475.5 \\
\hline Methanol & 1.05 & 1.1 \\
\hline 1-Propanol & 0.9 & 19.0 \\
\hline Isobutanol & 1.1 & - \\
\hline Isoamyl acetate & 54.7 & - \\
\hline 1-Butanol & 0.8 & - \\
\hline Isoamyl alcohol & 0.8 & 1.9 \\
\hline Hexanol & 0.6 & 1.2 \\
\hline Acetic acid & 1.2 & - \\
\hline 2,3-Butanediol & 1.5 & - \\
\hline Decanoic acid & 1.8 & 1.0 \\
\hline Lauric acid & 1.9 & - \\
\hline Benzyl alcohol & 1.4 & - \\
\hline
\end{tabular}




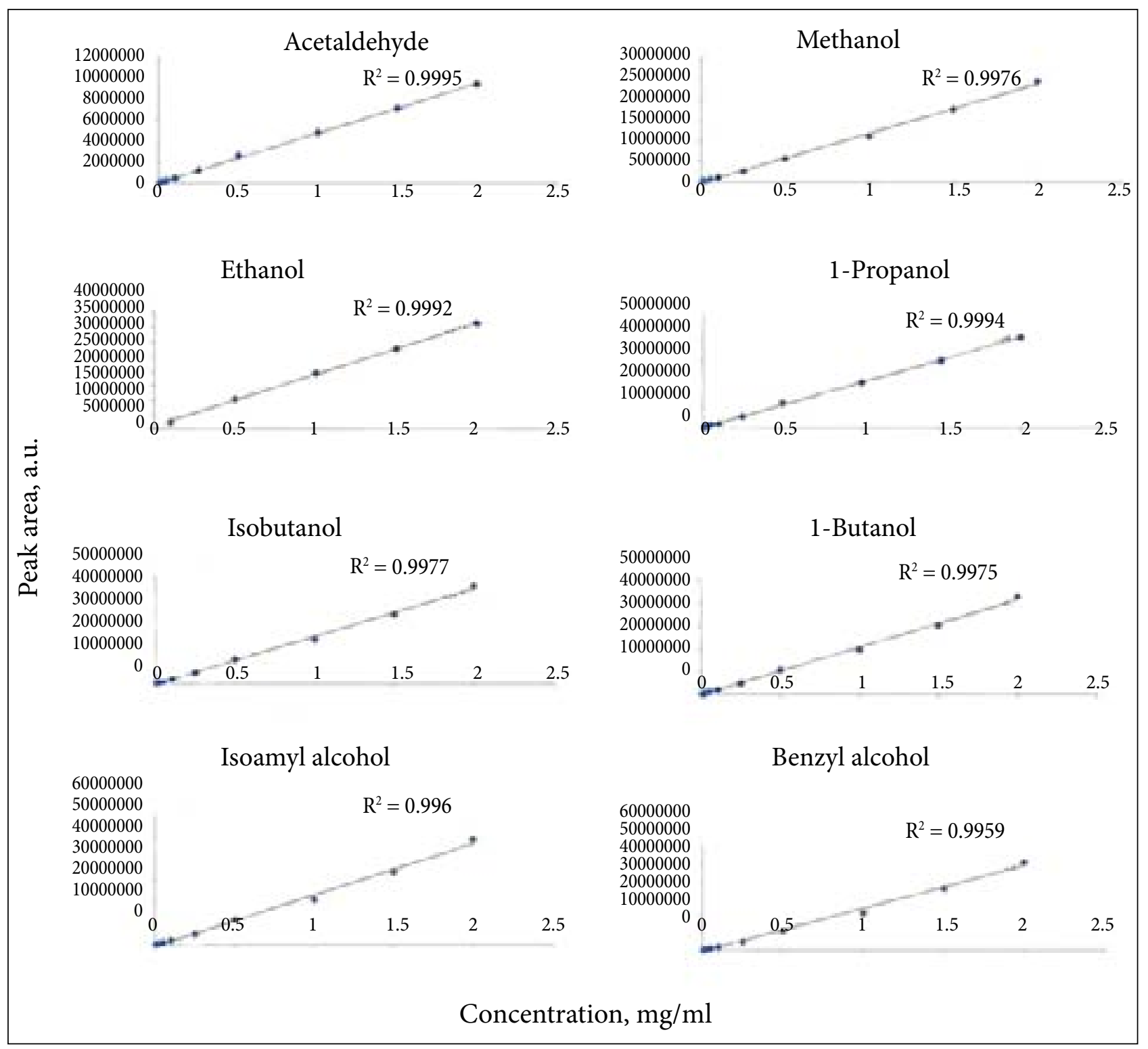

Fig. 4. The calibration curves used for the determination of different volatile compounds in three distillation fractions of cider brandy

correlation coefficients of $>0.99$. The preliminary concentrations of the compounds were estimated from these curves, however, for greater accuracy it was decided to narrow the calibration ranges. The trace concentrations of compounds were measured when the calibration curves ranged from 5 to $250 \mu \mathrm{g} / \mathrm{ml}$ and for higher concentrations the calibration curves from 0.25 to $2 \mathrm{mg} / \mathrm{ml}$ were used.

The analysis of the results for the determination of analytes in all three distillation fractions (Table 3) shows that the concentration of acetaldehyde gradually decreases from 957.1 to $22.5 \mathrm{mg} / \mathrm{ml}$ with increasing the distillation time. The concentration of methanol is very similar in all $\mathrm{A}, \mathrm{B}$ and $\mathrm{C}$ fractions. However, the concentration of etha- nol decreased significantly in the main fraction in comparison with the initial and intermediate fractions. The concentration of 1-propanol, isobutanol, 1-butanol and isoamyl alcohol in the fraction $\mathrm{C}$ decreased drastically as well. The amount of isobutanol, 1-butanol and isoamyl alcohol in the last fraction was lower than the limit of detection. It is interesting that the results of the determination of the concentration of benzyl alcohol show that the amount of this analyte increased in the main fraction. However, such results are probably related with a low selectivity of the determination of benzyl alcohol in the presence of a high amount of other volatile compounds in the fractions $\mathrm{A}$ and B. To summarize, the results of the quantitative 
Table 3. The results of the determination of analytes in all three distillation fractions of homemade cider brandy

\begin{tabular}{c|c|c|c}
\hline \multirow{2}{*}{ Analyte } & \multicolumn{3}{c}{ Concentration, $\mathbf{m g} / \mathbf{l}$} \\
\cline { 2 - 4 } & Fraction A & Fraction B & Fraction C \\
\hline Acetaldehyde & 957.1 & 213.2 & 22.5 \\
\hline Methanol & 26.2 & 14.1 & 21.7 \\
\hline Ethanol & 452000 & 511000 & 98000 \\
\hline 1-Propanol & 234.9 & 254.8 & 7.5 \\
\hline Isobutanol & 344.4 & 311.8 & $<\mathrm{n}$ \\
\hline 1-Butanol & 12.0 & 15.6 & $<\mathrm{n}$ \\
\hline Isoamyl alcohol & 661.1 & 824.8 & $<\mathrm{n}$ \\
\hline Benzyl alcohol & $<\mathrm{n}$ & $<\mathrm{n}$ & 24.8 \\
\hline
\end{tabular}

analysis confirm that longer distillation is necessary to reduce side volatile compounds in homemade cider brandy. The suitability of the proposed method for the determination of volatile analytes was also evaluated. The standard deviation (s) was varied in the range of $0.013-0.983$ with the relative standard deviation (RSD) in most of the cases lower than $18 \%$. These results confirm that small enough relative standard deviation values were obtained. It seems that the first two fractions of distillation of cider brandy should be re-distillated and the quality of the product could be improved [20, 22. However, the main fraction of home-made alcohol could be used in food industry without any limitation since the chemical composition is almost identical as those of similar commercial products [23-25]. For example, the propanol concentrations 6.61 and $22.88 \mathrm{mg} / \mathrm{l}$ determined in Calvados are treated as low and high, respectively [23]. Therefore, the home-made cider brandy produced in Lithuania contains a very low concentration $7.5 \mathrm{mg} / \mathrm{l}$ of propanol. However, this statement is attributed only to the distillation fraction C. On the other hand, the concentration of acetaldehyde should be reduced in the main fraction by double distillation [24].

\section{CONCLUSIONS}

In this work, the distillation fractions of cider brandy produced illegally in Lithuania using gas chromatographic-mass spectrometry method were investigated. A qualitative and quantitative analysis of three distillation fractions was performed and estimated. The first fraction (initial) of distillation products was collected for $0.5 \mathrm{~h}$, the second one (intermediate) was collected for the next $1.5 \mathrm{~h}$ and the third (main) fraction for the next $5 \mathrm{~h}$. It was shown that the compounds detected in the fractions were different because the fractions are collected by different time of distillations. The chromatograms of the first and the second fractions were similar only with different peak intensities. On the other hand, the initial fraction in comparison with the intermediate fraction contained extra volatile compounds, such as isobutyl acetate, ethyl butyrate, ethyl hexanoate and ethyl octanoate. Evidently, the main third fraction was the purest product of distillation. A significant decrease in the peak area of isoamyl acetate for the second fraction was clearly visible compared to that of the first fraction. Interestingly, the peak areas of acetaldehyde and 1-propanol for the main fraction were lower than in the initial fraction about 30 and 20 times, respectively. Moreover, the peak area of ethyl acetate decreased almost 475 times. The results of the quantitative analysis confirmed that the main fraction of home-made alcohol could be used in food industry without any limitation since the chemical composition is almost identical to the known similar commercial products. Therefore, the results obtained could serve as additional information for the responsible Lithuanian authorities to start the legalization processes of the fabrication of traditional home-made distilled strong alcoholic beverages.

Received 9 August 2021 Accepted 31 August 2021 


\section{References}

1. J. Mangas, R. Rodriguez, J. Moreno, D. Blanco, LWT-Food Sci. Technol., 29, 357 (1996).

2. W. Haider, D. Barillier, A. Hayat, J. L. Gaillard, J. Ledauphin, Analyt. Methods, 6, 1364 (2014).

3. H. Guichard, S. Lemesle, J. Ledauphin, D. Barillier, B. Picoche, J. Agric. Food Chem., 51, 424 (2002).

4. H. Mattsson, Calvados: The World's Premier Apple Brandy, Flavourrider.com, Malmo, Sweden (2004).

5. R. R. Madrera, J. J. M. Alonso, J. Agricult. Food Chem., 53, 3071 (2005).

6. S. A. Singerling, L. K. Burkemper, Z. D. Sharp, J. Agricult. Food Chem., 66, 11422 (2018).

7. N. Spaho, D. Dukic-Ratkovic, N. Nikicevic, et al., J. Inst. Brew., 125, 389 (2019).

8. T. E. Coldea, C. Socaciu, E. Mudura, et al., Food Chem., 320, 126643 (2020).

9. N. Spaho, F. Gasi, E. Leitner, et al., Foods, 10, 1258 (2021).

10. M. Sliwinska, P. Wisniewska, T. Dymerski, W. Wardencki, J. Namiesnik, Flav. Fragr. J., 30, 197 (2015).

11. Lietuvos Respublikos baudžiamasis kodeksas (Criminal Codex of the Republic of Lithuania), 207, Eugrimas, Vilnius (2021).

12. C. Da Porto, Crit. Rev. Biotechnol., 18, 13 (1998).

13. L. K. Ng, Anal. Chim. Acta, 465, 309 (2002).

14. D. H. Jernigan, Addiction, 104, 6 (2009).

15. X. N. Pang, J. Li, J. Y. Chen, L. J. Gao, B. Z. Han, J. Food Prot., 80, 431 (2017).

16. B. Plutowska, W. Wardencki, Food Chem., 107, 449 (2008).

17. S. Canas, Beverages, 3, 55 (2017).

18. G. Botelho, O. Anjos, L. M. Estevinho, I. Caldeira, Processes, 8, 1609 (2020).

19. S. Ramirez-Guizar, G. Gonzalez-Alatorre, M. C. I. Perez-Perez, A. Pineiro-Garcia, F. J. Lona-Ramirez, J. Food Meas. Charact., 14, 2059 (2020).

20. M. Esteban-Decloux, J. C. Dechatre, P. Legendre, H. Guichard, LWT-Food Sci. Technol., 146, 111420 (2021).

21. S. Charapitsa, S. Sytova, A. Kavalenka, et al., Food Anal. Methods, Early Access (2021).

22. Y. P. Zhao, T. T. Tian, J. M. Li, et al., Int. J. Food Eng., 10, 809 (2014).
23. J. Ledauphin, C. Le Milbeau, D. Barillier, D. Hennequin, J. Agric. Food Chem., 58, 7782 (2010).

24. Y. Zhao, Y. Xu, J. Li, W. Fan, W. Jiang, J. Food. Sci., 74, C90 (2009).

25. N. Spaho, F. Gaši, E. Leitner, et al., Foods, 10, 1258 (2021).

Indrè Vaičikauskytė, Vilius Poškus, Vytautas Nekrošius, Vida Vičkačkaitė, Aivaras Kareiva

\section{NAMU SĄLYGOMIS GAMINTAS SIDRO BRENDIS (KALVADOSAS): DISTILIACIJOS FRAKCIJU ANALIZE் DUJŲ CHROMATOGRAFIJOS-MASIŲ SPEKTROMETRIJOS METODU}

Santrauka

Šiame darbe dujų chromatografijos-masių spektrometrijos metodu pirmą kartą buvo tirta nelegaliai Lietuvoje pagaminto sidro brendžio distiliavimo frakcijų cheminè sudètis. Pirmiausia buvo optimizuotos duju chromatografijos-masių spektrometrijos analizès sąlygos. Buvo atlikta ir įvertinta trijų distiliavimo frakcijų kokybinè analizè. Pirmoji distiliavimo produktu frakcija (pradinè) buvo surinkta per 0,5 val., antroji (tarpinè) - per kitas 1,5 val., o kitas 5 valandas buvo surinkta trečioji (pagrindinè) frakcija. Kartu buvo sukurtas ịvairių lakiųjų junginių, tokių kaip acetaldehidas, metanolis, etanolis, 1-propanolis, izobutanolis, 1-butanolis, izoamilo alkoholis ir benzilo alkoholis, kiekybinès analizès distiliavimo produktuose metodas. Nustatyta, kad pagrindinejje frakcijoje labai sumažèjo etanolio koncentracija, palyginti su pradine ir tarpine frakcijomis. 1-propanolio, izobutanolio, 1-butanolio ir izoamilo alkoholio koncentracijos paskutineje frakcijoje taip pat smarkiai sumažejo. Kiekybinès analizès rezultatai patvirtino, kad pagrindinè naminio alkoholio dalis gali būti naudojama maisto pramoneje be jokiu apribojimų, nes cheminė sudètis yra beveik identiška žinomiems panašiems komerciniams produktams. Gauti rezultatai galètų būti papildoma informacija atsakingoms Lietuvos institucijoms siekiant pradeti tradicinių naminių distiliuotų stiprių alkoholinių gèrimų gamybos legalizavimo procesus. 